\title{
The impact of board oversight functions on the performance of listed companies in Nigeria
}

\author{
Ezekiel Oluwagbemiga Oyerogba ${ }^{a 1}$, Muyiwa Ezekiel Aladeb, \\ Patrick Esiemogie Idodec and Isaiah Ogungbade Oluyinkad
}

\author{
aBowen University, Nigeria \\ bAdekunle Ajasin University, Nigeria \\ 'Bells University of Technology, Nigeria \\ dAfe Babalola University, Nigeria
}

\begin{abstract}
A bstract: We ascertain the impact of board oversight functions on the financial performance of listed companies. The study covers the entire 186 companies listed on the Nigeria stock exchange for a period of five years between 2010 and 2014. Three aspect of board oversight function which includes the audit committee function, risk management committee function and remuneration/human capital committee function were considered in this study in line with the provision of (SEC) code of corporate governance and (OECD) code of corporate governance. Return on capital empl oyed and earnings per share were used as the measures of firm financial performance. We conducted both descriptive and inferential statistics on a set of data extracted from the audited financial statement of the listed companies. The descriptive statistics include the mean, standard deviation, minimum and maximum value for each variable while the inferential statistics includes the univariate t- test and multivariate regression analysis. The findings of this study reveal ed that board oversight function have significant impact on the financial performance of listed companies in Nigeria. The significant relationship between the board oversight functions and financial performance reported in this study have been asserted in previous literature in Africa (Beltratti \& Stulz, 2009) and Asia (Fahlenbrach \& Stulz, 2009; Fernandes \& Fich, 2009) which implies that this might be the global trend on the topic. Thus, the general hypothesis which predicts a significant
\end{abstract}

${ }^{1}$ Corresponding author: Department of Accounting, Bowen University, Iwo, Osun State, Nigeria; tel. +2348066308115; email: oyeezekie12903@yahoo.com 
relationship between board oversight function and firm financial performance cannot be rejected. Therefore, the recommendations emanating from this study is that concerted efforts should be put in place by the security and exchange commission to ensure strict compliance with regulations regarding the formation of audit committee and other oversight committees by the Nigerian listed companies.

Keywords: Board Oversight Functions, Audit Committee Functions, Risk Management Committee Functions, Remuneration Committee Functions, Retum on Capital Employed, Earnings per Share

\section{JEL CODE: M 41}

\section{Introduction}

In the emerging market, the concept of board oversight function is a hot issue for discussion because of series of crises witnessed in the recent times. These crises were perceived largely to be caused by series of factors among which the neglect of oversight functions was accorded higher points. Adams and Mehran (2003), while reporting on the root cause of the stock market crises of 2009 to 2011 posited that management were let loose to pursue their self-satisfying interest at the expense of the other stakeholders. Al-Shamari (2010) argued that board of directors is usually put in place to regulate the activities of the management but in actual sense they have been found to be mani pul ated by the management leading to loss of mandate to protect the shareholders and resulting in poor corporate performance. These findings bring into question whether it is reasonable to trust the board of directors with supervisory roles of corporate organizations, and prompts a critical examination of the impact of board oversight function on the performance of listed companies in Nigeria.

Good oversight function according to Ashley and Patel (2003) encourages management to sit tight and generate value for the organization, in term of innovation, development, growth and also promote good accountability to the shareholder and other stakeholders in a company. It also mitigates the agency problem which in turn leads to reduction in agency fees thereby increase the performance. In support of this position, Ongore (2011) attributed 37\% of the variation in the performance of listed companies in Ethiopia to the effective discharge of oversight functions by the board of directors. In like manner, the gl obal research efforts identified the failure of directors in overseeing the management as the bedrock of the corporate failure (Morgan \& Smircich, 1980; Cohen, 2002; Creswell \& Clark, 2011). 
In fulfilling the supervisory mandate of the directors, the key functions of the board are carried out through the board oversight committee (Adam \&Mehran, 2003). Therefore, three aspect of oversight function which includes the audit committee function, risk management committee function and remuneration/human capital committee function were considered in this study in line with the recommendation of security and exchange commission (SEC) code of corporate governance and organization for economic commission and devel opment (OECD) code of corporate governance. According to Hermalinand Weisbach (2003) although, oversight function may not be the direct determinant of performance in a company, however, adequacy of the oversight functions will determine the extent to which firms are vul nerable to poor performance.

Thus, this study was guided by three objectives. First, the study investigated the impact of audit committee functions on the performance of listed companies in Nigeria. The performance of listed firms is perceived largely to be subject to the effectiveness of oversight activities taken by the board of directors and audit committees to make sure that the financial reporting process is credible (Public Oversight Board, 1994). Also, effective audit committee function promotes the degree of responsibility that the executive directors and employees demonstrate towards the sharehol ders and other stakehol ders (Eighme \& Cashell, 2002) which in turn translate to higher retum on investments, sustainable growth, and reliable reporting on the financial performance and business practices of a company (Ljubisavljević \& J ovanovi, 2011).

Secondly, in the light of the fact that managerial excessive risk-taking behavior has been identified as one of the major causes of the current poor corporate performance, it indicates that in many companies, board of directors failed to set up appropriate risk strategies and monitor managers' risk taking behavior in a timely and effectively manner (Kirkpatrick, 2009). Therefore, this study set an objective which investigates the assumption that board oversight function (proxy by risk management function) will lead to enhanced corporate performance. Effective risk management is not only necessary for giving reasonably high returns to the shareholders but prudent risk management is also the key to avoiding financial distress that could later take the organization close to bankruptcy (AI-Shammari, 2010; Al-Matari et al.,2012).

The last objective of this study investigated the impact of remuneration committee functions on the performance of listed companies in Nigeria. The code of corporate governance by SEC (2011) requires all listed companies in Nigeria to establish a remuneration committee saddled with the responsibility of determining the job description of the executive directors and make recommendations on compensation structure for executive directors. The essence of this was to ensure that responsi bilities are matched with remuneration in order to attract the best empl oyees for the firm and thus improve the firm performance (Ashley \& Patel, 2003). It is 
believed that the use of attractive incentive mechanisms will help in aligning the interest of agents to those of principals and curb the CEO and top executives' opportunistic behavior in maximizing individual utility at the expense of sharehol ders (Williamson et al., 1975; Conyon, 2006; Core et al., 2005).

This study therefore makes significant contribution to the existing literatures on the impact of board oversight functions on firm performance. First, corporate board have unl imited function in a company which are basically strategic but their impact on firm performance are not homogenous (Billet al., 2012). Also, prior studies reported that certain board functions such as resources provision have significant influences on firm performance (Hermal in \& Weisbach, 2003; J enson, 1993; Linck et al., 2008), but, it does not imply that other board functions have the same impacts on firm performance. Therefore, this paper developed new evidence on the linkage between audit committee functions, risk management committee functions and remuneration committeefunctions on firm performance.

The second important contribution of this study was the construction of an index for the board oversight functions from the publicly disclosed information in the audited financial statement of the listed Nigerian companies using the security and exchange commission guidelines. Most prior studies used either survey responses through questionnaire or interview as a means of data collection (Mennon \& Williams, 1994; Song \& Subramaniam, 2005; Zainal \&t al, 2009) or dummy variable of either 1 or 0 for each of the three major oversight functions (Fadzil et al, 2005; Klein, 2002; Smith \& Watts, 1992). The survey result has been heavily criticized for over reliance on the opinion of certain individuals which might not be free from sample bias (Asley \& Patel, 2003; Conyon, 2006). The binary dummy on the other hand was perceived to be a narrow measure of oversight function (Brown \& Cayler, 2004). Therefore, unlike dummy variable used in the previous studies, the index constructed in this study captured all major aspect of board oversight functions; audit committee functions, risk management committee functions and remuneration committee functions. Up to 42 attributes that are rel ated to board oversight functions were captured in the construction of the oversight index and converted to percentage. The overall index is a weighted average of the scores given to the three components of board oversight functions with higher scores indicating better oversight function.

Furthermore, majority of the previous literatures on the impact of board oversight functions on firm performance focused on banks and other financial institutions which is an integral part of the listed companies (Brown \&Cayler, 2004; Fahlenbrach \& Stulz, 2009). This study differs from them as the study focus on the entire listed companies in Nigeria. Oversight functions in financial institutions are different from those of non financial institutions. Therefore, their findings cannot be directly general ized to all listed companies (eg., Adams \& Mehran, 2003; Andres \& 
Vallelado, 2008). Thus, necessitating the needs to carry out an elaborate study from which a general conclusion and recommendations can be drawn.

Similarly, the significant relationship between the board oversight functions and financial performance reported in this study have been asserted in previous literature in Africa (Beltratti \& Stulz, 2009) and Asia (Fahlenbrach \& Stulz, 2009; Fernandes \& Fich, 2009) which implies that this might be the global trend on the topic. Therefore, theliterature is useful for the Africa communities and the gl obal world.

The rest of the paper was structured as follows: the background of the study is presented in section 2; a review of relevant literature was carried out in section 3; the methodologies empl oyed in the study were detailed in section 4; the analysis and discussion of results was done in section 5 , while section 6 covers the conclusion and recommendation.

\section{Background of the study: Developments in the corporate governance practices in Nigeria}

The introduction of the Sarbanes Oxley (SOX) Act of 2002 by the market regulators in the United State can be considered as the clarion call for corporate governance development on a global scale. Specifically, the public awareness caused by SOX has triggered other sovereign states to improve on the existing code of corporate governance or introduce a code of corporate governance code where no code has been put in place earlier. This brings to the lime light the significance of adequate corporate governance practices towards promoting accountability and transparency of the financial reporting process. In Nigeria, corporate governance took his base from the Companies and Allied Matters Act 1990 as amended in 2004 (CAMA) which provided the legal framework for management of the affairs of public listed companies. This legal framework was tailored towards the AngloSaxon model of corporate governance because of the nation's historical background. However, combined with global events in financial reporting cycle and activities of some recognized institutional bodies, there is a renewed emphasis for an effective corporate governance practice. According to OFO, 2012, corporate governance emerged as a distinct concept in Nigeria with the issuance of the first Nigerian Code of Corporate Governance (NCCG) in the year 2003 by the Nigeria Securities and Exchange Commission (SEC). So far, most of the provisions contained in the NCCG, regulations and requirements currently in practice in Nigeria are sourced from key provisions of the Organization for Economic Cooperation and Development (OECD) on principles of corporate governance and other international corporate governance reports. 
The first code issued in 2003 identified the weaknesses in the existing legal framework and made recommendations based on gl obal ly acceptable practices. The introduction of this code was primarily aimed at stimulating accountability and transparency in the financial reporting process and also to serve as a guide to improving board efficiency (Okike, 2007). More importantly, the code enumerates the requirement for strengthening the board with respect to structure, composition and size, appointment of directors, board meetings and the board's fiduciary responsibilities, oversight functions and board committees. With respect to board composition, the code recommends that the board should be made up of both executive and non-executive directors and the board size should be determined in accordance with individual company's need. Similarly, the role of the chairman and that of the Chief Executive Officer (CEO) must be held by two separate individuals so as to preserve board independence However, where the same individual holds the two positions, then it is required that independent nonexecutive di rectors should dominate the board. Without doubt, the 2003 code is the forerunner to the development of other sectors' code of corporate governance and the 2011 revised NCCG.

As part of its continuous effort to strengthen corporate governance practices, a new code was issued by SEC on the $1^{\text {st }}$ of April 2011. The new code has a significant provision which distinguishes it from the 2003 code. Notable among the provisions are the need to have at least three oversight committees (Audit Committee, Risk Management Committee and Remuneration Committee) on the board to strengthen the financial reporting and internal control processes. The responsibilities, composition and structure of those committees were expl icit in the 2011 version of the code of corporate governance In addition, the presence of at least one independent non-executive director on the board is mandatory for all listed companies in the new code.

As recommended by the 2011 code, an audit committee is expected to range between 4 to 6 members with equal proportion of directors and representatives of shareholder. This committee is also required to have at least one member who is financial literate. The main responsibilities of this committee is to assist in the oversight of the integrity of the company's financial statements, ensure compliance with legal and other regulatory requirements, assessment of qualifications and independence of external auditor, establish an internal audit function and ensure there are other means of obtaining sufficient assurance of regular review or appraisal of the system of internal controls in the company, ensure the development of a comprehensive internal control framework for the company, obtain assurance and report annually in the financial report, on the operating effectiveness of the company's internal control framework, at least on an annual basis, obtain and review a report by the internal auditor describing the strength and quality of internal controls including any issues or recommendations for improvement, raised 
by the most recent internal control review of the company, discuss the annual audited financial statements and half yearly unaudited statements with management and external auditors, meet separately and periodically with management, internal auditors and external auditors, review, with the external auditor, any audit scope limitations or problems encountered and management's responses to same, review the independence of the external auditors and ensure that where non-audit services are provided by the External Auditors, there is no conflict of interest, preserve auditor independence, by setting clear hiring policies for employees or former employees of independent auditors (SEC, 2011)

The code also provided for the board to establish a Risk Management Committee to assist it in its oversight of the risk profile, risk management framework and the risk-reward strategy determined by the Board. The committee is given a mandate for the review and approval of the companies risk management policy including risk appetite and risk strategy, review the adequacy and effectiveness of risk management and controls, oversight of management's process for the identification of significant risks across the company and the adequacy of prevention, detection and reporting mechanisms, review of the company's compliance level with applicable laws and regulatory requirements that may impact the company's risk profile, periodic review of changes in the economic and business environment, including emerging trends and other factors relevant to the company's risk profile, and review and recommend for approval of the Board risk management procedures and controls for new products and services.

Accordingly, the remuneration/Governance committee who will perform the under listed functions among others must be made up of only the non-executive directors. The function of this committee is to establish the criteria for board and board committee memberships, review candidates qualifications and any potential conflict of interest, assess the contribution of current directors in connection with their renomination and make recommendations to the Board, prepare a job specification for the Chairman's position, including an assessment of time commitment required of the candidate, periodically eval uate the skills, knowledge and experience required on the Board, make recommendations on experience required by Board committee members, committee appointments and removal, operating structure, reporting and other committee operational matters, make recommendations on compensation structure for executive directors, provide input to the annual report of the company in respect of director compensation, ensure that a succession policy and plan exist for the positions of Chairman, CEO/MD, the executive directors and the subsidiary managing di rectors for Group companies and also review the performance and effectiveness of the subsidiary company Boards on an annual basis where applicable. 


\section{Board oversight function and firm performance: A review of empirical literature}

Faleye et al. (2009) conducted a study on the effects of the intensity of board monitoring on di rectors' effectiveness in performing their monitoring duties. Using data from the selected 10,636 firms on the US stock exchange for the year 1998 to 2006, the results shows that monitoring quality improves when a majority of independent directors serve on at least two of the three principal monitoring committees. These firms experience greater sensitivity of CEO turn over to firm profitability, lower excess executive compensation, and reduced earnings management. According to Faleye et al. (2009), the improvement in monitoring quality comes at the significant cost of weaker strategic advising and greater managerial myopia. It was also reported that Firms with boards that monitor intensely exhibit worse acquisition results and diminished corporate innovation. Firm val ue results suggest that the negative advising effects outweigh the benefits of improved monitoring, especially when acquisitions or corporate innovation are significant value drivers or the firm's operations are complex (Kashif, 2008; Inan, 2000; Hempel, 1998).

Y uqing et al. (2009) examined the relationship between executive compensation, board characteristics and firm performance in China: the impact of compensation committee based on the assumption that the independent directors of a board can impact CEO pay-performance more effectively if a compensation committee provides information and assist them in designing relevant executive pay schemes. On the basis of this idea, they developed and tested the hypotheses that Chinese firms with a compensation committee have a closer CEO pay link with performance when a larger proportion of independent directors serve on the board with primary focus on the effect of a compensation committee on CEO pay-performance relation as a consequence of its help for the board and found that board independence produces a stronger relationship between executive compensation and return on equity in Chinese listed firms. As reported in the study, this association is more evident in those firms which have a compensation committee than those without compensation committee. The findings as reported by Y uqing et al. (2009) also suggest that the interaction between independent directors on the board and compensation committee has important consequences for CEO incentive systems as well as corporate governance structures in China.

Similarly, Ebrahimet al. (2014) examined the relationship between audit committee characteristics and firm performance which is considered an oversight function of the board of directors. It also attempts to expl ore the moderating effect of the board diversity on the association between audit committee characteristics and firm profitability and to fill the gap in the existing literature that examined the 
relationship between corporate governance and firm performance in the developing countries. The data use for the study was comprised of 162 non-financial companies listed on Muscat Security Market (MSM) through 2011 and 2012. The study used some assumptions in order to test independent variables, moderating variables and dependent variables as reported by the authors. This study revealed a positive association between audit committee size and audit committee meeting to firm profitability but not significant. On the other hand, a negative but insignificant relationship was found between audit committee independence and firm profitability. Moreover, this study revealed that the foreign members of the board have a significant moderating effect on the relationship between audit committee independence and firm profitability. Therefore, there is a significant relationship between board oversight function and firm performance of listed companies in Nigeria.

Albert (2015) examined the effect of board committees on corporate financial performance among companies listed on the Ghana Stock Exchange (GSE). The quantitative research approach was adopted to study the prognostic effect of board committee on corporate financial performance for companies consistently listed on the GSE from 2006-2010 using data from the annual financial statement of listed companies with a static panel regression model used to analyze the presence of various committees on corporate financial performance. Albert (2015) finds that board committees had no statistical significant effect on the corporate financial performance of listed firms in Ghana. Specifically, nomination committee was negatively correlated with corporate financial performance and was statistically insignificant at the $5 \%$ level. Audit committee had no effect on corporate financial performance while remuneration committee produced positive correlation with corporate financial performance but al so not statistically significant at 5\% level of significance

\section{R esearch methodology and variables description}

The quantitative research method was adopted in this study to determine the impact of board oversight functions on the performance of listed companies in Nigeria. Quantitative research was adopted based on the perception of Conyol (2006) that quantitative research design is a means of testing the relationship between two or more variables via statistical analysis. The study covers the entire 186 companies listed on the Nigeria stock exchange for a period of five years between 2010 and 2014. According to SEC (2011), a period of three years was recommended for serving board member after which a director can be due for re-appointment or otherwise. This was to reduce the redundancy associated with long service by a board member and al so to integrate fresh and new ideas on the board as frequent as 
possible Therefore, five years measurement period was perceived long enough to reflect the impact of board oversight function on firm performance.

\subsection{Variable measurement}

\subsubsection{Board oversight function index}

In this paper, motivated by previous studied (Fahlenbrach \& Stulz 2009; Sudarat, 2006), an index was constructed for board oversight functions using corporate governance disclosure on board committees in the published audited financial statement of the 186 listed companies on the Nigeria stock exchange. Most previous studies on impact of board oversight functions on firm performance relied on survey responses from companies' directors or executives. Although a questionnai re can be designed to acquire in-depth information on board oversight functions, however, self-evaluation of one's performance may likely not pass objectivity test Consequently, a low response rate can be obtained and unrealistic conclusion can be drawn from the study.

Moreover, if directors with poor oversight functions were to protect themselves, then these survey-based ratings would not measure the adequacy of oversight functions at all. To circumvent these potential problems of survey-based oversight functions evaluation, the study relied only on public information available in the audited financial statement of each company to construct the oversight function index used in this study. The index ranges from 1 to 100 with higher value indicating better oversight functions. Using the OECD code of corporate governance and SEC code of corporate governance, a total of 42 items were included in the index under three major categories as audit committee functions, risk management functions and remuneration committee functions with the overall board oversight function index being the weighted average of the three categories. This is a more comprehensive measure of board oversight functions in Nigerian listed companies considering the fact that all crucial attributes of the oversight functions were captured in theindex. Details can befound in Appendix 1.

\subsubsection{Firm performance}

Similar to Abdullah (2004), Brown and Marcus (2006), Mitton (2002), Oyerogba et al. (2016), the study used retum on capital empl oyed and earnings per share as the primary measures of firm financial performance. This study adopted return on capital employed as a measure of performance for two important reasons. First, there appears to be a lack of consensus in the literature about the optimal measurement of financial performance (Mitton, 2002). Therefore, ROCE was focused on since is more commonly used in corporate governance literatures than the rest of financial performance measurements (Abdullah, 2004; Chen \& Lee, 
2008). Thus, adopting this measurement of performance will enable comparability of this study with existing literatures (Asley \& Patel, 2003; Druno \&Claessens, 2010; Renders, 2010; Price, 2011). Secondly, the use of accounting and marketbased measures of performance will provide a comprehensive check for the results (Asley \& Petal, 2003; Iman, 2002). Therefore, ROCE as proxies for company's performance help in measuring the impact of board oversight function on both accounting and market based performance.

Similarly, earnings per share calculated as the total earnings of a company that belong to common shareholders, divided by the number of common shares outstanding was adopted as a measure of financial performance for two principal reasons. First, earnings per share ratio (EPS ratio) measure the amount of a company's net income that is available for payment to the holders of its common stock (Miller \& Triana, 2009). A company with high earnings per share ratio is capable of generating a significant dividend for investors which is the ultimate aim of many investors (Mehrani, 1999). Secondly, earnings per common share are usually the first financial ratio investors look at when analyzing a stock (Ongore, 2011). Despite its simplicity, this metric is extremely powerful and condenses a great deal of crucial information into a single number (Oman, 2001) which al lows investors to compare alternative investments, chart the performance of a particular business over time and estimate the growth of her investments in the future (Sanda et al., 2005).

\subsubsection{Model specification}

The primary hypothesis of this study was that all things being equal, firms with better oversight functions records better performance during the period under consideration from which three other hypothesis were formulated using the three components of board oversight functions which are audit committee functions, risk management committee function and remuneration committee functions. Therefore, to provide evidence on the relationship between these variables, two models were estimated. The first model tested the relationship between the audit committee functions, risk management committee function, remuneration committee function and return on capital employed. The second model tested the relationship between the audit committee functions, risk management committee function, remuneration committee function and earnings per share. The models have been specified as follows:

$\mathrm{ROCE}_{\mathrm{t}}=\beta_{0}+\beta_{1} A C F_{\mathrm{t}}+\beta_{2} \mathrm{RMCF}_{\mathrm{t}}+\beta_{3} \mathrm{RCF}_{\mathrm{t} \varepsilon_{\mathrm{t}}}$

$E P S_{t}=\beta_{0}+\beta_{1} A C F_{t}+\beta_{2} R M C F_{t}+\beta_{3} R C F_{t} \varepsilon t$

Where:

ROCE $=$ Return on capital empl oyed

$\mathrm{EPS}=$ Earnings per share 
$A C F=$ Audit committee functions

$\mathrm{RMCF}=$ Risk management committee functions

$\mathrm{RCF}=$ Remuneration committee functions

$\beta_{0}=$ Represents the constant

$\varepsilon_{t}=$ Is the error term assumed to be normally distributed with zero mean and constant variance.

$\beta_{1}-\beta_{3}=$ Represents the coefficient of the independent variables.

\section{R esults and discussion}

\subsection{Descriptive statistics}

\subsubsection{Summary statistics}

Table 1 presents the summary statistics for the financial performance (return on capital employed and earnings per share) and board oversight functions (audit committee functions, risk management committee functions and remuneration committee functions) for a sample of 186 companies considered in this study. The summary statistics include the mean, standard deviation, minimum and maximum value for each variable. The overall board oversight functions ranges from 43.63 to 90.62 with a mean score of 64.95 on a scale of 0 to 100 with higher value indicating better oversight functions. The board oversight function result is by and large consistent with that of Sudarat (2006) on a sample of 365 listed Thailand companies where a mean score of 53.25 was obtai ned.

Table 1 al so revealed that an average audit committee in Nigerian listed company had a performance score of $58.99 \%$ with the least performing company scoring about $40 \%$ while the best performed audit committee got a score of 84.75 . Similarly, the results in table 1 reveal ed an average performance of about $74 \%$ for risk management committee functions with the worst performance of $53 \%$ indicating the relative importance attached to the risk management function by the listed companies in Nigeria. The average performance score for remuneration committee was 61.57 and varies widely across the study sample, ranging from 37.65 to 97.80. The results was however consistent with those of Mitton (2002) who reported a mean score of $57 \%$ for remuneration committee effectiveness and Macauley \& Randoy, (2013) whose mean score for remuneration committee function was $62 \%$.

Furthermore, the results of summary statistics for some firms attribute were presented in Table 2. A typical audit committee in Nigerian listed company consists of 4 to 7 members. Twenty two firms in the sample had 4 members in 
audit committee. Ninety one companies had 6 members in their audit committee, the maximum number allowed by CAMA (2004) while the remaining seventy three had either 5 or 7 members. Although, the size of the committee is not as significant as composition of the committee, however, it is believed that when a committee is too large, coordination and quorum issues are inevitable (Ademulegun, 2009). Therefore, in the composition of oversight index, 1 point was awarded if the committee comprises of 4 to 6 members and 0 if otherwise. On the composition of audit committee in Nigerian listed companies, the percentage of shareholders' representative in the audit committee of an average company in Nigeria was $46 \%$. This result shows a non-compliance with the provision of companies and allied matters, CAMA (2004), which requires that audit committee should comprise equal number of directors and representative of the shareholders.

As touching the risk management committee, the average size was 6.5 while the least and the largest were 4 and 8 respectively. Although a wide variation was discovered in the size of this committee, however, the quality of the risk management committee measured by the percentage of non-executive director to the total number in the committee where a mean score of $84 \%$ was obtained is encouraging. According to Sudarat (2006), non-executive directors, especially independent ones, are a mainstay of good governance. Their presence forms a balance with executive directors to ensure that an individual person or group cannot unduly influence the committee's decisions. Also, their independence enables them to act objectively and to exercise independent judgment regarding their tasks where there is a potential conflict of interest. In the sample for this study, non-executive directors make up about thre-quarter of the committee membership on average. About seventy percent of the companies in the sample have independent non-executive di rectors accounting for at least one-third of board membership. This is an improvement over the previous studies (Ademulegun, 2009)

In like manner, the size of remuneration committee in Nigerian listed companies ranges between 3 and 6 with a standard deviation of $0.11 \%$ showing more or less little or no variation. Also, this committee was made up of only non-executive directors showing a strict compliance with the provision of security and exchange commission code of corporate governance (SEC, 2011) which states that remuneration committee should comprise solely of non-executive directors. However, inclusion of independent non-executive director is still calling for improvement as ninety one companies were found to lack the presence of this category of director in the remuneration committee. This could probably be attributed to the limited number of independent non-executive directors on the board. 
Table 1. Summary statistics for dependent and independent variables

\begin{tabular}{|c|c|c|c|c|c|}
\hline & Mean & $\begin{array}{l}\text { Std. } \\
\text { Dev. }\end{array}$ & M inimum & M aximum & $\begin{array}{l}\text { No. } \\
\text { of O bs. }\end{array}$ \\
\hline $\begin{array}{l}\text { Overall Board Oversight } \\
\text { Functions }\end{array}$ & 64.95 & 11.77 & 43.63 & 90.62 & 186 \\
\hline Audit Committee Function & 58.99 & 11.26 & 40.26 & 84.75 & 186 \\
\hline $\begin{array}{l}\text { Risk MGT Committee } \\
\text { Function }\end{array}$ & 74.28 & 10.49 & 53.00 & 89.32 & 186 \\
\hline $\begin{array}{l}\text { Remuneration Committee } \\
\text { Function }\end{array}$ & 61.57 & 13.56 & 37.65 & 97.80 & 186 \\
\hline $\begin{array}{l}\text { Return on Capital } \\
\text { Employed }\end{array}$ & 0.83 & 0.22 & 0.15 & 3.57 & 186 \\
\hline Earnings per Share & 0.99 & 0.04 & 0.07 & 1.26 & 186 \\
\hline
\end{tabular}

Table 2. Summary statistics for firm's attribute

\begin{tabular}{|c|c|c|c|c|c|}
\hline & M ean & $\begin{array}{l}\text { Std. } \\
\text { Dev. }\end{array}$ & M inimum & Maximum & $\begin{array}{c}\text { No. } \\
\text { of Obs }\end{array}$ \\
\hline \multicolumn{6}{|l|}{ Audit Committee } \\
\hline Size of the Committee & 6 & 0.16 & 4 & 7 & 186 \\
\hline$\%$ of Non-Executive Directors & 46.24 & 8.44 & 42.50 & 67.77 & 186 \\
\hline$\%$ of Independent Directors & 21.45 & 2.63 & 19.12 & 28.54 & 186 \\
\hline \multicolumn{6}{|c|}{ Risk M anagement Committee } \\
\hline Size of the Committee & 6.50 & 1.25 & 4 & 8 & 186 \\
\hline$\%$ of Non-Executive Directors & 84.00 & 2.89 & 72.20 & 100.00 & 186 \\
\hline $\begin{array}{l}\% \text { of I ndependent Directors } \\
\text { R emuneration C ommittee }\end{array}$ & 23.71 & 0.44 & 20.00 & 26.29 & 186 \\
\hline Size of the Committee & 5.15 & 0.11 & & 6 & 186 \\
\hline$\%$ of Non-Executive Directors & 100.00 & 0.00 & 100.00 & 100.00 & 186 \\
\hline$\%$ of I ndependent Directors & 25.00 & 0.50 & 25.00 & 100.00 & 186 \\
\hline
\end{tabular}

\subsubsection{Trend analysis}

As part of the descriptive statistics, trend analysis was conducted for all the variables considered in this study. The essence of this was to anal yze the behavior of the data across the years and the sectors. Trend analysis provides a means to analyze company data over a period of time by focusing on the change in specific line items in the data (Albert, 2015). The trend analysis was done for the entire company for the five years ranging from 2010 to 2014. The full data was also partitioned into the eleven sectors considered in this study. The eleven sectors are Agriculture with 5 listed companies, Conglomerate with 6 listed companies, Construction/Real Estate has 9 listed companies, Consumer Goods with 27 listed companies, Financial Services has 56 listed companies, Healthcare is having 11 listed companies, Information/Communication has 9 listed companies, Industrial Goods with 21 listed companies, Natural Resources with 5 listed companies, Oil 
and Gas has 14 listed companies, and Services with 23 listed companies. For the purpose of this analysis, the sectors were labeled 1 to 11 respectively. The results were presented in Figures 1 to 4.

Figure 1 shows the results of the trend analysis for return on capital employed on yearly basis, which revealed a significant increase in return on capital employed between 2010 and 2011. A slight decrease was experience in 2012. The trend however recorded another significant increase in return on capital employed in the year 2013 to 2014. The fall in return on capital employed in 2012 can be attributed to the global financial crises which occurred within that period as well as the financial market reform that took place in Nigeria within that period. However, the positive macroeconomic policies put in place by the government might be responsible for the rise in those years following the fall. Also, considering the fact that 2012 represents the first reporting year after the new code of corporate governance was implemented, it is not unreasonable to expect such performance. Therefore, the rise in performance in the subsequent years could be a confirmation of the effectiveness of the new code which is very explicit about the board oversight functions.

In the same manner, earnings per share witnessed a significant increase across all the years under consideration except 2011 when there was a reduction of about $5 \%$ from what it was in 2010. Although the fall in 2011 is marginal and economically insignificant, it could be a signal for the need for constant review of the corporate governance code as this year marks the end of the old corporate governance code. Generally, the performance of the listed companies can be considered satisfactory owing to the fact that earnings per share increased from 0.66 to 1.53 within the shortest period of five years.

Similarly, the trend analysis for return on capital employed for all the eleven sectors considered in this study was presented in figure 2 . It can be observed from the results that financial institution had the best performance in terms of retum on capital employed during the period under consideration, followed by oil and gas sector while the service industry recorded the worst performance in terms of retum on capital employed. Also, it was observed that seven out of eleven sectors had return on capital employed above 0.5 indicating that the companies have been performing reasonably well. Zinglermy (2012) fixed the acceptable return on capital employed of listed companies in Tai wan at 0.4 for financial institutions, 0.3 for manufacturing companies and 0.25 for conglomerate. Consistent with ROCE, the trend analysis result for EPS can also be considered satisfactory. Although, slightly lower than ROCE, the best performance was also recorded by financial institution and all the sectors recorded an EPS that is higher than 0.5 except healthcare sector and services industry whose EPS were 0.38 and 0.22 respectively. 
Furthermore, the trend analysis results for the overall board oversight function s as well as the three components of the oversight functions for the five years under consideration were presented in figure 3 . It is obvious that the highest performance of overall board oversight function occurred in 2014 while the least discharge of oversight function occurred in 2010. For the audit committee function, the best discharge of this function occurred in 2014 while the least was done in 2011. Pertaining to risk management committee function, the listed companies had the highest discharge of this function in 2014 with the lowest done in 2010. Remuneration committee on the other hand had the best discharge of her duties in 2013 and the worst discharge of duties in 2010. Maj ority of the variables recorded the best performance in 2014, suggesting that the new code of corporate governance had a de layed effect on the discharge of board oversight function.

Again, the sectorial trend analysis results for board oversight function were presented in figure 4. From these results, a serious fluctuation was observed. However, financial institution appeared to have the best overall oversight performance. The result is not unexpected owing to the fact that firms in the financial sector tend to be scrutinized more intensively than other sectors of the economy because of the sensitive nature of their job. This sector is also being regulated by two other regulatory bodies (Central Bank of Nigeria and Nigeria Deposit Insurance Corporation) in addition to the security and exchange commission which place higher responsibility on the board of these companies in terms of monitoring. Apart from the financial institutions, companies in industrial goods recorded the best oversight function in terms of audit committee functions with a mean score of about $65 \%$. Companies in conglomerate can be consi dered to have the highest oversight functions in terms of risk management function with a mean score of 92.21 while the best oversight function in terms of remuneration committee was recorded by the companies classified as natural resources with an average score of about $70 \%$.

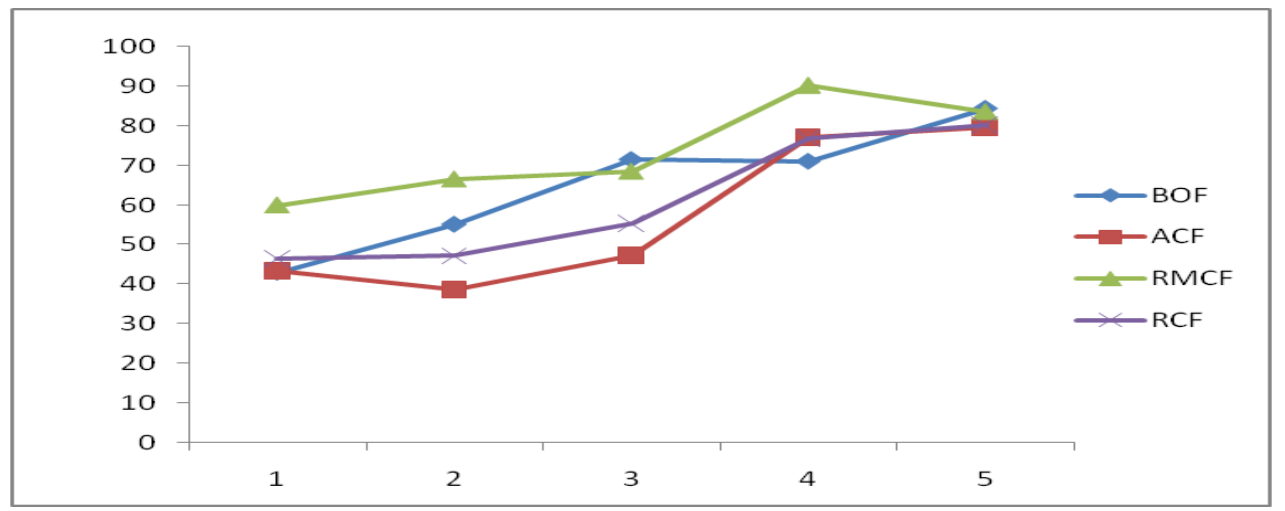

Figure 1. Trend analysis for BOF across the years 


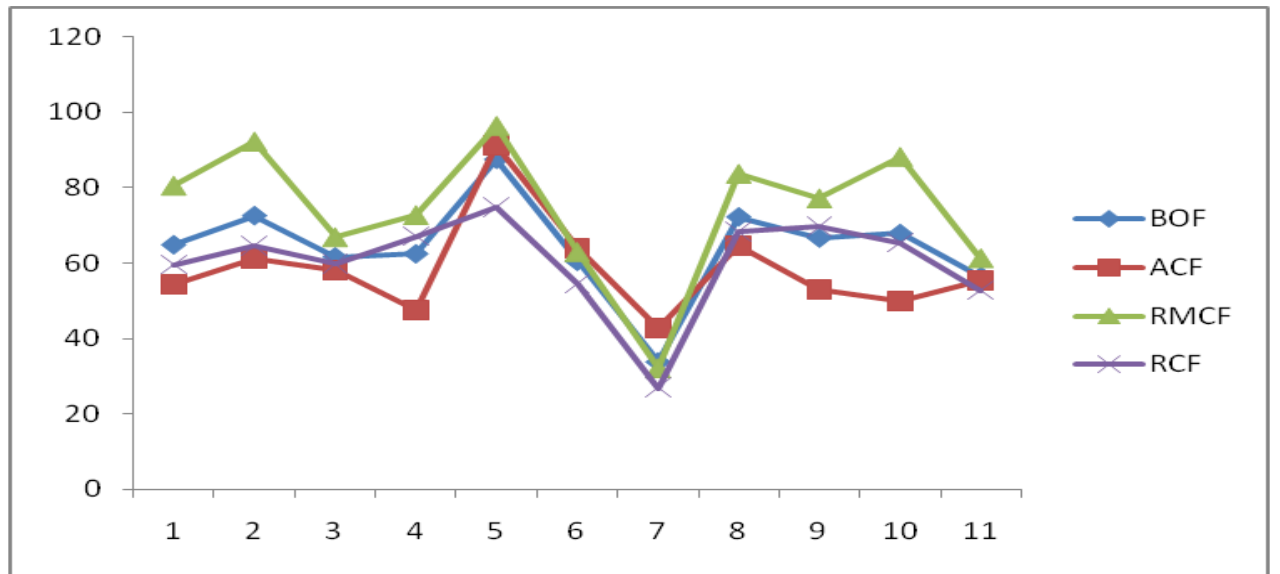

Figure 2. T rend analyses for BOF across the sectors

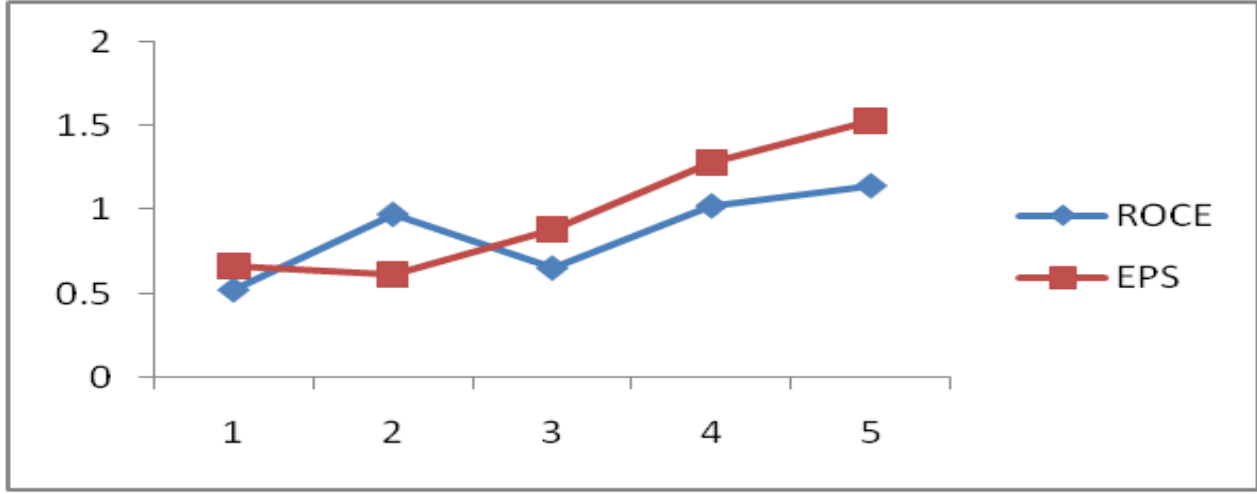

Figure 3. Trend analysis for ROCE and EPS across the years

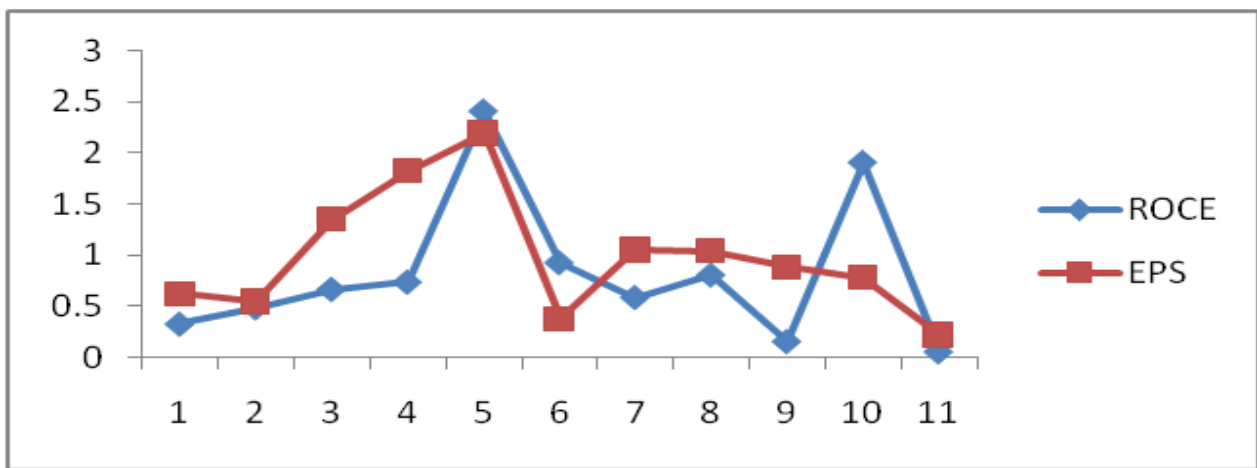

Figure 4. T rend analyses for ROCE and E PS across the sectors 


\subsection{Inferential statistics and test of hypothesis}

\subsubsection{Univariate results on board oversight functions and firm's financial performance}

The primary hypothesis of this study was that, ceteris paribus, firms with adequate board oversight functions have better performance in terms of return on capital employed and earnings per share. Therefore, to provide some empirical evidence on this hypothesis, univariate comparison of the mean of retum on capital employed and earnings per shares for firms with different oversight functions results was conducted. First and foremost, the sample was divided into two subgroups based on the median value of board oversight functions. The median value was 52.85. Eighty nine firms scored an oversight results below the median score while ninety seven firms scored above the median value. It was further discovered that the mean ROCE was 0.73 for the firms with oversight function below the median while it was 0.91 for firms with board oversight functions above the median. Notably, a significant difference of 0.18 and t-statistics of 2.69 between these two subsamples seems to exist with regard to Return on capital employed during the periods under consideration. Similarly, the mean of EPS for the firm with board oversight function below the median was 0.86 while the EPS of 1.12 was obtained for the firms with board oversight functions above the median, resulting in a significant difference of 0.26 and t-statistics of 2.41 as reported in table 3. The result was not surprising given the fact that Faleye et al. (2009) reported that firms experience greater sensitivity of CEO turn- over to firm profitability, lower excess executive compensation, and reduced earnings management where boards monitor intensely.

Accordingly, the full sample for audit committee functions was al so separated into two sub-samples based on the median value (median value was 45.20). Here, the mean of ROCE was 0.98 for the firms who scored below the median score in audit committee functions, and it 0.67 for firms with audit committee functions above the median value The mean difference of -0.31 was obtained with a t-statistics of 3.19 which was significant at the $5 \%$ level of significance. In like manner, the mean value of EPS was 1.17 for the firms who scored bel ow the median value in audit committee functions while it was 0.82 for the firms who score above the median val ue in audit committee functions which resul ted in a mean difference of 0.35 and t-statistics of 2.72. The result is somewhat worrisome, indicating that firms with better audit committee functions had worse performance than firms with inadequate audit committee functions. However, the result is not unacceptable given the facts that previous literatures have shown inverse and insignificant relationship between audit committee functions and firm performance (Albert, 2015; A bdullah et al., 2014). 
Furthermore, the full sample was separated into two subsamples for the risk management committee functions. It was discovered that the average ROCE was 0.73 for firms with inadequate risk management functions while it was 0.92 for firms with adequate risk management functions. The mean difference of 0.19 with t-statistics of 2.91 was significant at the $5 \%$ level of significance, suggesting that firms with adequate risk management committee function perform much better than firms with inadequate risk management committee functions. Similarly, the EPS comparison for the two subsamples where a mean of 0.77 was obtained for the firms who scored bel ow the median score in risk management committee functions and 1.21 for those who scored above the median val ue produced a mean difference of 0.44 and t-statistics of 4.11 which was statistically significant at the $5 \%$ level of significance. The result provides preliminary evidence of the link between the risk management committee functions and financial performance of the listed companies.

Lastly, the sample for remuneration committee function was divided into two subsamples. Ninety two companies scored bel ow the median value with an average of 0.79 ROCE while ninety four companies were in the latter category with an average of 0.85 ROCE. The results showed a mean difference of 0.06 and tstatistics of 1.16 implying that no significant difference was found between the performance of firms with efficient remuneration committee and those with inefficient remuneration committee Similarly, no significant difference seems to exist between the performances of the firms who scored above the median value and those who scored bel ow the median value in respect to EPS, which produced a mean difference of 0.08 and t-statistics of 1.31 for the period under consideration. This result validates the findings of Albert (2015) who reported that remuneration committee produced positive correlation with corporate financial performance but not statistically significant at $5 \%$ level of significance

Summarily, the results of the univariate analysis revealed that board oversight function have significant impact on the financial performance of listed companies in Nigeria. Thus, the general hypothesis which predicts a significant relationship between board oversight function and firm financial performance cannot be rejected. The results also indicated that certain board oversight functions such as audit committee function and risk management committee functions have significant impact on the financial performance of thelisted Nigeria companies.

Table 3. Univariate results

\begin{tabular}{lllllllllll}
\hline & \multicolumn{3}{c}{ Below median } & \multicolumn{3}{c}{ A bove median } & \multicolumn{3}{c}{ Difference } & \multicolumn{2}{c}{ T-Statistics } \\
& N & ROCE & EPS & N & ROCE & EPS & ROCE & EPS & ROCE & EPS \\
\hline BOF & 89 & 0.73 & 0.86 & 97 & 0.91 & 1.12 & 0.18 & 0.26 & 2.69 & 2.41 \\
ACF & 84 & 0.98 & 1.17 & 102 & 0.67 & 0.82 & -0.31 & -0.35 & 3.19 & 2.72 \\
RMCF & 108 & 0.73 & 0.77 & 78 & 0.92 & 1.21 & 0.19 & 0.44 & 2.91 & 4.11 \\
RCF & 92 & 0.79 & 0.95 & 94 & 0.85 & 1.03 & 0.06 & 0.08 & 1.16 & 1.31 \\
\hline
\end{tabular}




\subsubsection{M ultivariate results on board oversight functions and firm's financial performance}

To further investigate the impact of board oversight functions on firm financial performance, a multivariate regression analysis was conducted using the three components of the board oversight functions (audit committee functions, risk management committee function and remuneration committee function) on two measures of performance (return on capital empl oyed and earnings per share). The overall board oversight function index was removed from the multivariate model to avoid multicolinearity problems since the three components were al ready induded in the overall index. The results were presented in Tables 4 and 5.

As reported in Tables 4 and 5, the beta coefficient for audit committee function was negatively correlated with the two measures of financial performance (return on capital employed and earnings per share) and significant at $5 \%$ level of significance indicating that firms with less audit committee functions performs better than those with strong audit committee functions. The resul ts were consistent with the univariate test and most previous literature that found negative relationship between audit committee and financial performance of publicly quoted companies (Jensen, 1993; Lipton \& Lorsch, 1992; Shaver, 2005; Smith \& Wood, 2009). It however contradicts the agency theorists that argue that in order to protect the interests of shareholders; the board of directors must assume an effective oversight function through audit committee (Donal dson \& Davie, 1994). Globally, it is assumed that the presence of an audit committee provides a reasonable assurance to the reliability of reporting process of the firm and also improves the performance (Fernandes \& Fich, 2009). This gl obal view of the agency theory was substantiated by studies in emerging economy using Sri Lanka as a case study where Heenetigala (2011), found a positive relationship between corporate governance structures (board committees)and firm performance which was proxy by higher profitability and share price performance.

However, the critics of agency theory have posited that audit committee does more harm to the firm than good. According to Baber et al., (1996) audit committee oversees the management generally by functioning as constraints on them Therefore, rather than contributing to firm performance, this view has management driving firm performance, with the audit committee imposing limits to the way in which managers are free to pursue shareholder value Furthermore, in discussing the importance of audit committee, being to check managerial self-serving behavior, Bebchuk and Fred (2006) posited that the devices, mechanisms, and structures to reduce self-serving behavior of management hamper performance and, while improving accountability, actually reduce efficiency. Another factors attributable to the negative relationship between audit committee and financial performance in Nigeria context and other Emerging economy as identified from the 
literature was that, in maj ority of the listed companies (more than 80 percent), audit committees are weakly constituted with majority of the members lacking the necessary qualities of integrity, dedication, adequate audit skills and thorough understanding of the business of the company among others (Modum et al., 2013; Shamsudden, 2003). Thus, this result supports the criticism against the conventional agency theory and questioned the assumption that audit committee functions will lead to enhancefinancial performance.

Also in table 4, the beta coefficient for risk management committee function was 0.208 and statistical ly significant at $5 \%$ level of significance, suggesting that return on capital empl oyed for firms with efficient risk management committee was 0.208 higher than for firms with inefficient risk management committee. Similarly, in table 5 , the beta coefficient for the relationship between the risk management committee functions and earnings per share was 0.517 which is statistically significant at $5 \%$ level of significance. The result indicated that an improvement in risk management committee function by the listed companies leads to an increase in earnings per share by 0.517 , an effect which is economically meaningful. With this results, a casual relationship that board oversight functions have significant impact on firm financial performance can be asserted. The result val idates those of Chen \& Lee (2008) and Andres \& Vallelado (2008) on a global level, as well as those of Soyemi et al. (2014) in Nigeria and Omatese (2012), Zimbabwe Shungu et al. (2014) and Zubairi \& Alson (2015) in other emerging economies.

The effect of remuneration committee functions on financial performance is ambiguous. On one hand, retum on capital empl oyed was inversely correlated with remuneration committee. On the other hand, earnings per share were positively correlated with remuneration committee functions. However, the dichotomy is negligible since the coefficients were insignificant indicating that remuneration committee functions have no impact on the financial performance of listed companies in Nigeria. The results appear inconsistent with those of Bebchuk \& Fred (2006) and Chen \& Lee (2008) who reported a strong relationship between remuneration committee and firm performance. Furthermore, it is consistent with more recent literature such as Albert (2015) who found a positive but insignificant relationship between the remuneration committee and corporate financial performance of listed companies in Ghana.

Table 4. Regression results for board oversight functions and ROCE

\begin{tabular}{|c|c|c|c|c|c|}
\hline \multicolumn{2}{|r|}{$\mathbf{R}$} & \multicolumn{4}{|c|}{$R^{2}$} \\
\hline & 0.477 & & & 0.228 & \\
\hline Regression & $\begin{array}{c}\text { SS } \\
1439.457\end{array}$ & $\begin{array}{c}\text { DF } \\
3\end{array}$ & $\begin{array}{c}\text { M S } \\
479.819\end{array}$ & $\begin{array}{c}\mathbf{F} \\
43.529\end{array}$ & $\begin{array}{l}\text { Sig. } \\
0.000\end{array}$ \\
\hline Residual & 2017.225 & 183 & 11.023 & & \\
\hline Total & 3456.682 & 186 & & & \\
\hline
\end{tabular}




\begin{tabular}{lllrl}
\hline \multicolumn{1}{c}{$\mathbf{R}$} & \multicolumn{3}{c}{$\mathbf{R}^{2}$} \\
\hline & Beta & Std. Err & T-Stat & Sig \\
Audit Committee Function & -0.374 & 0.102 & -3.667 & 0.000 \\
Risk MGT. Committee Function & 0.208 & 0.074 & 2.811 & 0.000 \\
Remuneration Committee Function & -0.139 & 0.114 & -1.209 & 0.233 \\
\hline
\end{tabular}

Note: Dependent Variable: Return on Capital Employed

Table 5. R egression results for board oversight functions and EPS

\begin{tabular}{|c|c|c|c|c|c|c|}
\hline \multicolumn{2}{|l|}{ 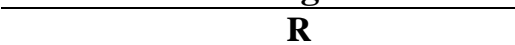 } & \multicolumn{5}{|c|}{$\mathbf{R}^{2}$} \\
\hline \multicolumn{2}{|r|}{0.525} & \multicolumn{5}{|c|}{0.276} \\
\hline \multirow{4}{*}{$\begin{array}{l}\text { Regression } \\
\text { Residual } \\
\text { Total }\end{array}$} & SS & DF & MS & \multirow{2}{*}{$\begin{array}{c}\mathbf{F} \\
34.101\end{array}$} & \multirow{2}{*}{\multicolumn{2}{|c|}{$\begin{array}{l}\text { Sig. } \\
0.000\end{array}$}} \\
\hline & 1239.458 & 3 & 413.163 & & & \\
\hline & 2217.223 & 183 & 12.116 & & & \\
\hline & 3456.682 & 186 & & & & \\
\hline & & B eta & Std. & & T-Stat & Sig \\
\hline Audit Com & e Function & -0.401 & 0.15 & & -2.261 & 0.000 \\
\hline Risk MGT. & mittee Function & 0.517 & 0.17 & & 2.888 & 0.000 \\
\hline Remunerati & ommittee Function & 0.236 & 0.26 & & 0.884 & 0.294 \\
\hline
\end{tabular}

Note: Dependent Variable: Eamings per Share

\section{Conclusion and recommendations}

In this paper, the impact of board oversight functions on the financial performance of listed companies in Nigeria was investigated for a period of ten years between 2005 and 2014. A comprehensive oversight index was constructed from the audited financial statement of the 186 listed companies in Nigeria using the guidelines in the security and exchange commission and organizations for economic commission and development code of corporate governance. Up to 42 attributes that are related to board oversight functions were captured in the construction of the oversight index under three categories; audit committee functions, risk management committee functions, remuneration committee functions and converted to percentage. Potential problems associated with firm size were controlled by using percentage and binary variables for all the components in the variables for the study.

The results of this study challenge the conventional wisdom and the agency theory school of thought and conclude that monitoring will not always lead to better performance. Empirical evidence in this paper suggests that audit committee function have adverse effect on retum on capital employed and earnings per share. This negative effect was maintained by both univariate and multivariate results, a position earlier reported by Albert (2015) and contradicted by J osiah (1998) and Landvel (2001). The positive and significant relationship between the risk 
management committee functions and return on capital employed and earnings per share reported in this study have been asserted in previous literature except that only financial institutions were considered (Beltratti \& Stulz, 2009; Fahlenbrach \& Stulz, 2009; Fernandes \& Fich, 2009). Therefore, this study contributes to the existing literatures by discovering that risk management committee function is essential for both financial and non financial institutions.

Unexpectedly, this study also found an insignificant relationship between the remuneration committee function and earnings per share as well as return on capital employed. The two possible explanations for this result could be that efficiency of this committee in the determination of remuneration of the top management staff played down the moral of the management which was the case in Ethiopia (Conyon, 2006), Malaysia (Abdullah, 2004) and Tanzania (J ames \& Willey 2009). Secondly, the pay-for-performance reward schemes advocated by the remuneration committee of most listed companies in Nigeria might be a bad motivation for the management (Cheng \& Firth, 2005). We therefore encourage the future studies to investigate the impact of pay for performance reward on financial performance of listed companies in Nigeria and beyond.

Notwithstanding the limitations that this study might have encountered, the results of this study have implications for policy makers and regulatory bodies. First, noncompliance with the provision of companies and allied matter act, CAMA (2004) was discovered in the composition of audit committee in the listed companies in Nigeria. Therefore, concerted efforts should be put in place by the security and exchange commission to ensure strict compliance with regulations regarding the formation of audit committee and other oversight committees by the Nigerian listed companies. Secondly, the negative impact of audit committee functions on financial performance suggests an overbearing effect of audit committee functions on performance of the management. Therefore, a clear specification and review of audit committeefunction needs to be carried out by the regul atory authorities.

\section{R eferences}

Abdullah, S. N (2004) "Board composition, CEO duality and performance among Malaysian listed companies", International J ournal of Business in Society, vol. 4(4): 47-61

Adams, R.\& Mehran, H. (2003) "Is corporate governance different for bank holding companies?", Economic Policy Review, vol. 9, 123-142

Albert, P. (2015) "Do board committees affect corporate financial performance? Evidence from listed companies in Ghana", International J ournal of Business and Management Review, vol. 3(5): 14-25 
Al-Matarneh, G.F. (2011) "Factors determining the internal audit qual ity in banks: Empirical evidencefrom Jordan", International Research Journal of Finance and Economics, vol. 7(3): 99-108

Al-Matari, E.M., Al-Swidi, A.K., Faudziah, H.B., \& Al-Matari, Y.A. (2012) "The Impact of board characteristics on Firm Performance: Evidence from nonfinancial listed companies in Kuwait stock exchange", International J ournal of Accounting and Financial Reporting, vol. 2(2): 310-332

Andres, P.D.\&Vallelado, E., (2008) "Corporate governance in banking: The role of the board of directors", J ournal of Banking \& Finance, vol. 32: 2570-2580

Ashley, A. \& Patel, J. B. (2003) "The impact of leadership characteristics on firm performance", International J ournal of Value-Based Management, vol. 16(3): 211-222

Bebchuk, L.A. \& Fried, J.M. (2006)“Pay without performance: Overview of the issues", Academy of Management Perspectives vol. 20: 5-24

Baber, W.R., Janakiraman, S.N. \& Kang, S-H.(1996) "Investment opportunities and the structureof executive compensation", J ournal of Accounting and Economics, vol. 21(3): 297-318

Bathala, C.T. \& Rao, R.P. (1995) "The determinants of board composition: an agency theoryperspective", Managerial and Decision Economics, vol. 1(4)6: 59-69

Bhagat, S.\& Black, B.S., (2001) “The non-correl ation between board independence and long-term firm performance", J ournal of Corporation Law vol. 27: 231-273

Brown, L.D. \& Caylor, M. L. (2004) "Corporate governance and firm performance", Working paper, Georgia StateUniversity

Brown, L.D. \&Marcus, C.L. (2006) "Corporate governance and firm valuation", J ournal of Accounting and Public Policy, vol. 25 (4)

Chen, M.\& Lee, K. (2008) "Compensation, corporate governance and owner sharehol ding: Theory and evidence from family ownership", International Researchl ournal of Finance and Economics, vol. 7(22): 144-161

Cohen, J. (2002) "Corporate governance and the audit process", Contemporary Accounting Research, vol. 19(4): 573-94

Conyon, M.J. (2006) "Executive compensation and incentives", Academy of Management Perspectives, vol. 20(1): 25-44

Core, J. E., Guay, W. R. \& Thomas, R. S. (2005) "Is U.S. CEO compensation inefficient pay without performance", Michigan Law Review, vol. 103(5): $1142-1185$

Croswell, A.T. \& Clark, S.L. (2011) "Discretionary disclosure of reserves by oil and gas companies: an economic analysis", J ournal of Business Finance and Accounting, vol. 19(2): 295-308

Donaldson, L. \& Davis, J.H. (1994) "Boards and company performance: research challenges", Corporate Governance: An International Review, vol. 2(6): 151-160 
Ebrahim, M.A.,Faudziah, K.A. \& Abdullah, B.F (2014) "The effect of the internal audit and firm performance: A proposed research framework", International Review of Management and Marketing, vol. 4 (1): 34-41

Eighme, J \& C Cashell, J . (2002) "Internal auditors' roles in overcoming the financial reporting crisis", International Auditing, vol.17(2): 3-10

Fadzil, F.H., Haron, H.\&J antan, M. (2005) "Internal auditing practices and internal control system", Managerial Auditing J ournal, vol. 20(8):844-866

Faleye, O., Hoitash, R., \&Hoitash, U. (2009) "The costs of intense board monitoring" , J ournal of Financial Economics, vol. 10(1): 160-181

Fahlenbrach, R.\&Stulz, R.M., (2009) "Bank CEO Incentives and the credit crisis",Unpublished working paper, Swiss Finance Institute

Fernandes, N.,\& Fich, E.M., (2009) “Does financial experience help banks during credit crises", Unpublished working paper, Drexel University

Hampel, R. (1998) "Committee on Corporate Governance: Final Report", London: Gee Publishing

Hermal in, B.E., \&Weisbach, M.S., (2003) “Boards of directors as an endogenously determined institution: a survey of the economic literature", Economic Policy Review vol. 9: 7-26

Imam S. (2000) "Corporate social performance reporting in Bangladesh", Managerial Auditing J ournal, vol. 15(3): 133-141

Jensen, M. (1993) "The modern industrial revolution, exit and the failure of internal control systems", J ournal of Finance, vol. 48: 831-880.

Kirkpatrick, G., (2009) "Corporate governance and the financial crisis", Working paper, OECD

Klein, A., (2002) Audit committee, board of director characteristics, and earnings management, J ournal of Accounting and Economics, vol. 33(2): 375-400

Linck, J.S., Netter, J .M., \&Y ang, T., (2008) "The determinants of board structure", J ournal of Financial Economics, vol. 8(7): 308-328

Lipton, M., \& Lorsch, J.W., (1992) "A modest proposal for improved corporate governance", Business Lawyer, vol. 48: 59-77

Ljubisavljević, S., \& J ovanovi, D. ( 2011) "Empirical research on the intemal audit position of companiesin Serbia", Economic Annals, vol. 19(1): 123-141

Mehrani, H (1999) "Executive compensation structure, ownership, and firm performance", J ournal of Financial Economics, vol. 3(8):163-184

Mennon, K. \& Williams, J.D, (1994) "The use of audit committee for monitoring", J ournal of Accounting and Public Policy, vol. 13(4): 121-139

Miller, T. \& M. Triana, (2009) "Demographic diversity in the boardroom Mediators of the board diversity-firm performance relationshi p", J ournal of Management Studies, vol. 46(5): 755-786

Mitton, T. (2002) "A cross-firm analysis of the impact of corporate governance on the East Asian financial crisis", J ournal of Financial Economics, vol. 6(4): 215-241

Morgan, G. \& Smircich, L. (1980) "The case for qual itative research", Academy of Management Review, vol. 5(4): 491-500 
OECD (1999) "OECD Principles of corporate governance", Ad-Hoc Task Force report on Corporate Governance, Paris

Ogbechie, C. (2006) "Corporate governance: A challenge for Nigerian banks", Retrieved on $7^{\text {th }}$ August, 2014 fromwww.Businessdayonl ine.com

Oman, C. P. (2001) "Corporate Governance and National Development", OECD Devel opment Center Technical Papers, vol. 180: 362-388

Ongore, V.O. (2011) "The relationship between ownership structure and firm performance: An empirical analysis of listed companies in Kenya", African J ournal of Business Management, vol. 5(2): 2120-2128

Oyerogba, E.O. Memba, F. \&Riro, G.K (2016) “Impact of board size and firm's characteristics on the profitability of listed companies", Research J ournal of Finance and Accounting, vol. 7 (4): 143-151

Sanda, A.U., Mukaila, A.S., \&Garba, T. (2005) "Corporate governance mechanisms and firm's financial performance in Nigeria", AERC Research Paper, No. 149

SEC (2011) "Code of corporate governance for public companies", retrieved on $28^{\text {th }}$ August, 2013 from http://www.sec.gov.ng/

Shaver, D. (2005) "Characteristics of corporate boards in singleindustry and conglomerate media companies", International Journal of Media Management, vol. 7(34): 112-120

Smith, M. (1996) "Sharehol ders activism by institutional investors: Evidence from CALPERS", J ournal of Finance, vol. 51(1): 227-252

Smith, C. \& Watts, R. (1992) "The investment opportunity set and corporate financing, dividend and compensation policies", J ournal of Financial Economics, vol. 32(3): 509-522

Song, S.L. Ali, R. \&Subramaniam P. (2005) "Ownership structure, motives and corporate takeover performance of Malaysian public listed firms", Capital Market Review, vol. 13 (2), 1-19

Sudarat, A. (2006) “Does foreign investment really improve corporate governance? Evidence from Thailand", University of California Draft 
Appendix 1: Composition of B oard O versight F unctions I ndex

\begin{tabular}{|c|c|c|c|c|}
\hline Code & Question & Scoring R ule & $\begin{array}{l}\text { Max. } \\
\text { Score }\end{array}$ & W eight \\
\hline 1 & A udit Committee & & 16.00 & $100 \%$ \\
\hline $1 a$ & What is the size of Audit Committee & $\begin{array}{l}1 \text { if } 4<=1 \mathrm{la}<=6 ; 0 \\
\text { otherwise }\end{array}$ & 1.00 & \\
\hline $1 b$ & $\begin{array}{l}\text { How many representatives of } \\
\text { sharehol ders are in audit committee }\end{array}$ & $\begin{array}{l}1 \text { if } 1 b / 1 a>=1 / 2 ; 0 \\
\text { otherwise }\end{array}$ & 1.00 & \\
\hline 1c & $\begin{array}{l}\text { How many Directors are in Audit } \\
\text { Committee }\end{array}$ & $\begin{array}{l}1 \text { if } 1 c / 1 a>=1 / 2 ; 0 \\
\text { otherwise }\end{array}$ & 1.00 & \\
\hline $1 d$ & $\begin{array}{l}\text { Internal audit unit report directly to the } \\
\text { audit committee }\end{array}$ & $\begin{array}{l}1 \text { if } 1 d=1 ; 0 \\
\text { otherwise }\end{array}$ & 1.00 & \\
\hline le & $\begin{array}{l}\text { Audit committee review the scope and } \\
\text { planning of audit requirements }\end{array}$ & $\begin{array}{l}1 \text { if } 1 e=1 ; 0 \\
\text { otherwise }\end{array}$ & 1.00 & \\
\hline If & $\begin{array}{l}\text { Audit committee review the findings on } \\
\text { management matter in conjunction with } \\
\text { External Auditor }\end{array}$ & 1 if $1 \mathrm{f}=1 ; 0$ otherwise & 1.00 & \\
\hline $1 g$ & $\begin{array}{l}\text { Audit committee does periodic review } \\
\text { of the effectiveness of the system of } \\
\text { accounting and internal control }\end{array}$ & 1 if $1 g=1 ; 0$ otherwise & 1.00 & \\
\hline Ih & $\begin{array}{l}\text { Audit committee make } \\
\text { recommendations to the AGM in } \\
\text { regard to appointment, removal and } \\
\text { remuneration of external auditor }\end{array}$ & $\begin{array}{l}1 \text { if } 1 \mathrm{~h}=1 ; 0 \\
\text { otherwise }\end{array}$ & 1.00 & \\
\hline $1 i$ & $\begin{array}{l}\text { Audit committee Authorize internal } \\
\text { auditor to conduct periodic } \\
\text { investigations into the company's } \\
\text { activities }\end{array}$ & $\begin{array}{l}1 \text { if } 1 \mathrm{i}=1 ; 0 \\
\text { otherwise }\end{array}$ & 1.00 & \\
\hline 1j & $\begin{array}{l}\text { Audit committee assess the } \\
\text { performance of the internal audit } \\
\text { function }\end{array}$ & $\begin{array}{l}1 \text { if } 1 \mathrm{j}=1 ; 0 \\
\text { otherwise }\end{array}$ & 1.00 & \\
\hline $1 \mathrm{k}$ & $\begin{array}{l}\text { Audit committee meet separatel y and } \\
\text { periodical ly with management, internal } \\
\text { auditor and external auditor }\end{array}$ & $\begin{array}{l}1 \text { if } 1 k=1 ; 0 \\
\text { otherwise }\end{array}$ & 1.00 & \\
\hline 11 & $\begin{array}{l}\text { Audit committee review and ensure } \\
\text { that adequate whistle-bl owing } \\
\text { procedure is in place }\end{array}$ & $\begin{array}{l}1 \text { if } 11=1 ; 0 \\
\text { otherwise }\end{array}$ & 1.00 & \\
\hline $1 \mathrm{~m}$ & $\begin{array}{l}\text { Audit committee review, with the } \\
\text { external auditor, any audit scope, } \\
\text { limitation or problems encountered and } \\
\text { management response }\end{array}$ & $\begin{array}{l}1 \text { if } 1 \mathrm{~m}=1 ; 0 \\
\text { otherwise }\end{array}$ & 1.00 & \\
\hline In & $\begin{array}{l}\text { Audit committee review the } \\
\text { independence of the external auditors }\end{array}$ & $\begin{array}{l}1 \text { if } 1 n=1 ; 0 \\
\text { otherwise }\end{array}$ & 1.00 & \\
\hline 10 & $\begin{array}{l}\text { Audit committee preserves auditor } \\
\text { independence, by setting clear hiring } \\
\text { policies for employees and independent } \\
\text { auditor }\end{array}$ & $\begin{array}{l}1 \text { if } 10=1 ; 0 \\
\text { otherwise }\end{array}$ & 1.00 & \\
\hline
\end{tabular}




\begin{tabular}{|c|c|c|c|c|}
\hline Code & Q uestion & Scoring Rule & $\begin{array}{l}\text { Max. } \\
\text { Score }\end{array}$ & W eight \\
\hline $1 p$ & $\begin{array}{l}\text { Audit committee consider any related } \\
\text { party transactions that may arise within } \\
\text { the company or group }\end{array}$ & $\begin{array}{l}1 \text { if } 1 p=1 ; 0 \\
\text { otherwise }\end{array}$ & 1.00 & \\
\hline 2 & Risk M anagement Committee & & 12.00 & $100 \%$ \\
\hline $2 a$ & $\begin{array}{l}\text { What is the size of risk management } \\
\text { committee }\end{array}$ & $\begin{array}{l}1 \text { if } 4<=2 a<=6 ; 0 \\
\text { otherwise }\end{array}$ & 1.00 & \\
\hline $2 \mathrm{~b}$ & $\begin{array}{l}\text { What is the total number of executive } \\
\text { directors in the committee }\end{array}$ & $\begin{array}{l}1 \text { if } 2 \mathrm{~b} / 2 \mathrm{a}>=1 / 3 ; 0 \\
\text { otherwise }\end{array}$ & 1.00 & \\
\hline $2 \mathrm{c}$ & $\begin{array}{l}\text { What is the total number of non- } \\
\text { executive director in the committee }\end{array}$ & $\begin{array}{l}1 \text { if } 2 c / 2 a>=2 / 3 ; 0 \\
\text { otherwise }\end{array}$ & 1.00 & \\
\hline $2 d$ & $\begin{array}{l}\text { The committee does the review of } \\
\text { company risk policy }\end{array}$ & $\begin{array}{l}1 \text { if } 2 \mathrm{~d}=1 ; 0 \\
\text { otherwise }\end{array}$ & 1.00 & \\
\hline $2 e$ & $\begin{array}{l}\text { committee review the adequacy and } \\
\text { effectiveness of risk management and } \\
\text { control }\end{array}$ & $\begin{array}{l}1 \text { if } 2 \mathrm{e}=1 ; 0 \\
\text { otherwise }\end{array}$ & 1.00 & \\
\hline $2 f$ & $\begin{array}{l}\text { The committee does oversight of } \\
\text { management's process for the } \\
\text { identification of significant risk across } \\
\text { the company }\end{array}$ & $\begin{array}{l}1 \text { if } 2 f=1 ; 0 \\
\text { otherwise }\end{array}$ & 1.00 & \\
\hline $2 g$ & $\begin{array}{l}\text { The committee does the review of the } \\
\text { company's compl iance level with } \\
\text { applicable laws and regul ations }\end{array}$ & $\begin{array}{l}1 \text { if } 2 \mathrm{~g}=1 ; 0 \\
\text { otherwise }\end{array}$ & 1.00 & \\
\hline $2 \mathrm{~h}$ & $\begin{array}{l}\text { The committee does periodic review of } \\
\text { changes in the economic and business } \\
\text { environment }\end{array}$ & $\begin{array}{l}1 \text { if } 2 \mathrm{~h}=1 ; 0 \\
\text { otherwise }\end{array}$ & 1.00 & \\
\hline $2 i$ & $\begin{array}{l}\text { The committee review and recommend } \\
\text { for approval of the Board risk } \\
\text { management process and control for } \\
\text { new products }\end{array}$ & $\begin{array}{l}1 \text { if } 2 \mathrm{i}=1 ; 0 \\
\text { otherwise }\end{array}$ & 1.00 & \\
\hline $2 \mathrm{j}$ & $\begin{array}{l}\text { A seni or management staff is detailed } \\
\text { to perform the function and attend the } \\
\text { meeting or risk management committee }\end{array}$ & $\begin{array}{l}1 \text { if } 2 \mathrm{j}=1 ; 0 \\
\text { otherwise }\end{array}$ & 1.00 & \\
\hline $2 \mathrm{k}$ & $\begin{array}{l}\text { The CEO/MD, executive directors and } \\
\text { head of the internal audit unit attend } \\
\text { meeting of risk management committee }\end{array}$ & $\begin{array}{l}1 \text { if } 2 \mathrm{k}=1 ; 0 \\
\text { otherwise }\end{array}$ & 1.00 & \\
\hline 21 & $\begin{array}{l}\text { The committee establish annual risk } \\
\text { limit for the company }\end{array}$ & $\begin{array}{l}1 \text { if } 2 \mathrm{l}=1 ; 0 \\
\text { otherwise }\end{array}$ & 1.00 & \\
\hline 3 & Remuneration Committee & & 14.00 & $100 \%$ \\
\hline $3 a$ & $\begin{array}{l}\text { What is the size of remuneration } \\
\text { committee }\end{array}$ & $\begin{array}{l}1 \text { if } 4<=3 a<=6 ; 0 \\
\text { otherwise }\end{array}$ & 1.00 & \\
\hline $3 b$ & $\begin{array}{l}\text { The committee comprise of only the } \\
\text { non-executive directors }\end{array}$ & $\begin{array}{l}1 \text { if } 3 b=1 ; 0 \\
\text { otherwise }\end{array}$ & 1.00 & \\
\hline $3 c$ & $\begin{array}{l}\text { The committee establish the criteria for } \\
\text { board and board committee }\end{array}$ & $\begin{array}{l}1 \text { if } 3 c=1 ; 0 \\
\text { otherwise }\end{array}$ & 1.00 & \\
\hline
\end{tabular}




\begin{tabular}{|c|c|c|c|c|}
\hline Code & Q uestion & Scoring R ule & $\begin{array}{l}\text { Max. } \\
\text { Score }\end{array}$ & W eight \\
\hline & membership & & & \\
\hline $3 d$ & $\begin{array}{l}\text { The committee review directors } \\
\text { qual ifications }\end{array}$ & $\begin{array}{l}1 \text { if } 3 \mathrm{~d}=1 ; 0 \\
\text { otherwise }\end{array}$ & 1.00 & \\
\hline $3 e$ & $\begin{array}{l}\text { The committee prepare a job } \\
\text { specification for the chairman's } \\
\text { position }\end{array}$ & $\begin{array}{l}1 \text { if } 3 e=1 ; 0 \\
\text { otherwise }\end{array}$ & 1.00 & \\
\hline $3 f$ & $\begin{array}{l}\text { The committee periodically eval uate } \\
\text { the skills, knowl edge and experience } \\
\text { required of the CEO and management } \\
\text { staff }\end{array}$ & $\begin{array}{l}1 \text { if } 3 f=1 ; 0 \\
\text { otherwise }\end{array}$ & 1.00 & \\
\hline $3 g$ & $\begin{array}{l}\text { The committee make recommendations } \\
\text { on appointments and removal of CEO }\end{array}$ & $\begin{array}{l}1 \text { if } 3 g=1 ; 0 \\
\text { otherwise }\end{array}$ & 1.00 & \\
\hline $3 h$ & $\begin{array}{l}\text { The committee make recommendations } \\
\text { on remuneration structure for executive } \\
\text { directors }\end{array}$ & $\begin{array}{l}1 \text { if } 3 \mathrm{~h}=1 ; 0 \\
\text { otherwise }\end{array}$ & 1.00 & \\
\hline $3 i$ & $\begin{array}{l}\text { The committee make recommendations } \\
\text { on compensation package for non } \\
\text { executive directors }\end{array}$ & $\begin{array}{l}1 \text { if } 3 i=1 ; 0 \\
\text { otherwise }\end{array}$ & 1.00 & \\
\hline $3 j$ & $\begin{array}{l}\text { The committee provide input to the } \\
\text { annual report of the company in respect } \\
\text { to directors' compensation }\end{array}$ & $\begin{array}{l}1 \text { if } 3 j=1 ; 0 \\
\text { otherwise }\end{array}$ & 1.00 & \\
\hline 3k & $\begin{array}{l}\text { The committee ensure that a succession } \\
\text { policy and exist plan for the position of } \\
\text { Chairman, CEO and other executive } \\
\text { directors }\end{array}$ & $\begin{array}{l}1 \text { if } 3 \mathrm{k}=1 ; 0 \\
\text { otherwise }\end{array}$ & 1.00 & \\
\hline 3l & $\begin{array}{l}\text { It ensure that the Board conducts } \\
\text { annual appraisal of the management }\end{array}$ & $\begin{array}{l}1 \text { if } 3 \mathrm{l}=1 ; 0 \\
\text { otherwise }\end{array}$ & 1.00 & \\
\hline $3 m$ & $\begin{array}{l}\text { The committee review the performance } \\
\text { and effectiveness of the subsi diary } \\
\text { company' board annually }\end{array}$ & $\begin{array}{l}1 \text { if } 3 m=1 ; 0 \\
\text { otherwise }\end{array}$ & 1.00 & \\
\hline $3 n$ & $\begin{array}{l}\text { The committee ensure that the } \\
\text { company undertake a periodic peer } \\
\text { review of its compensation }\end{array}$ & $\begin{array}{l}1 \text { if } 3 n=1 ; 0 \\
\text { otherwise }\end{array}$ & 1.00 & \\
\hline
\end{tabular}

